\title{
Reinforcement Level: An Analysis Teacher in Junior High School Teacher
}

\author{
Citra Maulidia ${ }^{1 *}$, Herman Nirwana ${ }^{2}$, Marlina Marlina ${ }^{3}$ \\ 1,2,3Universitas Negeri Padang \\ *Corresponding author, e-mail: citramaulidya@yahoo.com
}

\begin{abstract}
The implementation of the learning process cannot be separated from the existence of the teacher. The creation of an effective learning atmosphere requires a close relationship between teachers and students. The reinforcement given by the teacher affects the level of student activity and participation in the learning process. In schools there are still teachers who are not appropriate to implement reinforcement. This can be seen in the poorly educated treatment of teachers towards students, such as yelling at students in public, and negative labelling of students.The purpose of this study was to describe the level of reinforcement of subject teachers in Padang City Junior High School. This research uses a quantitative descriptive approach. The research sample consisted of 149 students who were taken using the purposive random sampling technique. The instrument used was the "Teacher Reinforcement Scale" with a reliability value of 0.714 . The results of this study reveal that the reinforcement of subject teachers in schools is in a low category. The results of the study generally show that the reinforcement of subject teachers is in a low category and needs to be improved in order to encourage students to be more active in participating in the learning process. The results of this research can be used as a basis for school counselors or Guidance and Counseling teachers in providing guidance and counseling services in schools by involving subject teachers.
\end{abstract}

Keywords: Teacher, Reinforcement level

How to Cite: Maulidia, C., Nirwana, H., Marlina. M. (2021). Reinforcement Level: An Analysis Teacher in Junior High School Teacher. International Journal of Applied Counseling and Social Sciences, VV (N): pp. 108-116, DOI: http://doi.org/10.24036/005415ijaccs

\section{Introduction}

The teacher is one of the determining factors for the success of any educational effort. The role of teachers in the world of education greatly determines the success or failure of education. Teachers play a strategic role, especially in an effort to shape the character of the nation through the development and value of the desired values (Koswara, 2008). Teachers are not only teachers, but also educators (Sardiman, 2007). Student attitudes and behavior are influenced by teaching practices and teacher emotional support (Blazar\& Kraft, 2017). Therefore, the teacher is expected to become an educator, teacher, and guide in order to 
improve student achievement and foster student motivation in learning. To produce quality students, competent teachers are needed. Competent teachers will be better able to create an effective learning process and be able to manage the class.

The learning theory from Skinner's behavioristic psychology, which states that the reward and reinforcement that teachers give to students is the most important factor in the learning process (Soemanto, 2006). Providing reinforcement by the teacher in the learning process is an effort to develop student personalities in achieving educational goals, especially with regard to acceptable behavior. Providing reinforcement will affect the level of student activity and participation, so it can be said that providing important reinforcement in the learning process.

Providing reinforcement in the learning process aims to increase student motivation to carry out positive behaviors that support success in the learning process. In line with what was stated (Darmadi, 2010) that providing appropriate reinforcement to students can increase student attention to the learning process, arouse, maintain behavior, foster self-confidence, and maintain a conducive learning climate. Broadly speaking, it can be interpreted that the provision of reinforcement as a positive response aims to maintain and increase the positive actions carried out by students in their learning activities so that students are motivated to improve learning outcomes and repeat them. Furthermore, Hasibuan\&Moedjiono (2009) also suggest that it is rare to provide reinforcement to students in the learning process, but teachers still often ignore it even though these activities are very important and easy to do.

In general, the low level of teachers in schools provides reinforcement for students ( $\mathrm{Al}$ Halik, Prayitno, \&Mudjiran, 2019). The results of the research by Aini, Nirwana, \&Marjohan (2018) show that teacher reinforcement is in the sufficient category with a percentage of $41 \%$ and in the less category with a percentage of $4 \%$, Abdillah's research results (2009) also show that the reinforcement aspect is in the lowest category in application authority in three schools with a percentage of $75.10 \%, 67.69 \%$, and $65.97 \%$. Student opinions about the reinforcement given by the teacher are in the sufficient category with a percentage of $76.59 \%$ (Al Halik et al., 2019). Prayitno (2005) also revealed that teachers tend not to provide improvements to the tasks done by students with a percentage of $17.9 \%$. Some of the results of these studies indicate that the reinforcement of subject teachers provided to students in the learning process is quite low.

Teacher characteristics, teacher performance in teaching is a factor that influences student learning behavior in learning (Elliot, Kratochwill, Littlefied, \& Travers, 1996). The reinforcement given by the teacher to students is in the form of rewards or praise, so students are motivated and more ready to accept subject matter (Aini, Nirwana, \&Marjohan, 2018). So teachers are not only transferring knowledge but also educating students to be good citizens, to become students with good personalities and whole. Educating also means transferring values to students, these values must be manifested in daily behavior. Therefore, the teacher's person himself is the embodiment of the values that will be transferred. So the teacher does not only act as a teacher who transfers values, the teacher is not only a carrier of knowledge, but the teacher is also a good example for students and their surroundings.

There are two types of reinforcement, namely positive reinforcement, and negative reinforcement. Basically, the two reinforcement is given with the intention of reinforcement behavior and avoiding unsatisfactory behavior. The purpose of giving reinforcement by teachers to students is to attract and maintain students 'attention to continue to participate and 
encourage them to try harder to always behave positively and to increase students' selfconfidence to manage themselves in learning (Rasto, 2015).

Based on the results of research on high touch teachers in the city of Padang which compared expectations and reality with the acquisition of an expectation score of 8.2 and a reality score of 9.1 in the recognition aspect. In the aspect of affection and tenderness, the score was 8.1 on the reality score and 9.1 on the expectation score. In the aspect of reinforcement, the expected score is 9 while the reality score is 7.8. In the aspect of educational assertiveness, an expectation score of 9 was obtained while in reality a score of 8 was obtained. In the direction aspect, the expected score was 9 and the reality score was 9 . In the exemplary aspect, the expectation score was 9, while the real score was 8. ,4. So it can be concluded that of the six aspects, only one score was higher than the expectation score, namely in the aspect of recognition, while other aspects such as affection and tenderness, educational assertiveness, reinforcement, direction, and exemplary scored lower than the score hope. So, there is a significant difference between reality and expectations. The implementation of high-touch teachers is needed so that the learning process is conducive and achieves the learning objectives as expected (Ningsih, Marjohan, \&Nirwana, 2018). The educational situation grows and develops, one of which is through the aspect of reinforcement the teacher (Prayitno, 2009). Based on the above problems, this study aims to analyze the ability of teachers to provide reinforcement. Based on the previous explanation, it is seen how the teacher's high touch picture in the aspect of reinforcement. Furthermore, the results of this study can be the basis for making guidance and counseling programs in schools.

\section{Method}

This research method uses quantitative methods with descriptive analysis (Kothari, 2004). Descriptive research is research that provides a more detailed description of a symptom or phenomenon (Prasetyo\&Jannah, 2012). Quantitative research methods provide quantitative descriptions or numbers and are analyzed using statistics (Creswell, 2009; Sugiono, 2012). The population in this study were students of SMP Negeri Kota Padang in the academic year 2020/2021, totaling 780 students. The research sample consisted of 149 students who were taken using the purposive random sampling technique.

The instrument used in this study was the "Teacher Reinforcement Scale" in the form of a Likert scale. Test the validity of the instrument using the Product Moment Correlation formula. "Teacher Reinforcement Scale" with a reliability value of 0.714 . Data were analyzed using descriptive analysis. The research data was processed using the help of statistical products and service solutions (SPSS) version 20.00. Descriptive analysis techniques are used to see an overview of the level of reinforcement of subject teachers.

Table 1. Research Sample ( $\mathrm{n}=149$ students of Padang City State Junior High School)

\begin{tabular}{cc}
\hline Class & Total \\
\hline IX 1 & 32 \\
IX 2 & 30 \\
IX 3 & 30 \\
IX 4 & 29 \\
IX 5 & 28 \\
Total & 149 \\
\hline
\end{tabular}




\section{Results and Discussion}

Based on the results of data analysis related to the level of reinforcement teacher at Junior High School, the following description.

Table 2. Teacher reinforcement at SMP Negeri Kota Padang ( $\mathrm{n}=149$ students)

\begin{tabular}{ccccc}
\hline Interval & Categories & F & $\%$ \\
\hline$\geq 94$ & Very High & 4 & 2.7 \\
$76-93$ & High & 41 & 27.5 \\
$58-75$ & & Moderate & 46 & 30.9 \\
$40-57$ & & Low & 58 & 38.9 \\
$\leq 39$ & & Very Low & 0 & 0 \\
& Total & & 149 & 100 \\
\hline
\end{tabular}

Based on table 1, the overall teacher reinforcement is in the "low" category with a score of $38.9 \%$. Teacher reinforcement is obtained from all aspects of reinforcement, namely positive verbal reinforcement, non-verbal positive reinforcement, mixed positive reinforcement, and negative reinforcement. The results of this study are supported by research results (Ismeirita, 2020) which show teacher reinforcement is in the low category with a percentage of $51.39 \%$. The results of this study also showed that the reinforcement of teachers at the Padang City Junior High School was also in the low category. So it is necessary to increase the reinforcement of teachers so that the student learning process goes according to the expected goals.

Table 3. Teacher reinforcement based on sub-variables at SMP Negeri Padang City ( $n=149$ students)

\begin{tabular}{|c|c|c|c|c|c|c|}
\hline No & \multicolumn{2}{|c|}{ Sub Variabel } & Categories & \multirow{2}{*}{$\frac{\text { Interval }}{\geq 18}$} & $\mathrm{f}$ & \multirow[b]{2}{*}{16.1} \\
\hline \multirow[t]{6}{*}{1} & Verbal & Positive & Very high & & 24 & \\
\hline & Reinforcement & & High & $15-17$ & 38 & 25.5 \\
\hline & & & Moderate & $12-14$ & 40 & 26.8 \\
\hline & & & Low & $9-11$ & 44 & 29.5 \\
\hline & & & Very low & $\leq 8$ & 3 & 2.0 \\
\hline & & & & & 149 & 100.0 \\
\hline \multirow[t]{6}{*}{2} & Non Verbal & Positive & Very high & $\geq 18$ & 26 & 17.4 \\
\hline & Reinforcement & & High & $15-17$ & 28 & 18.8 \\
\hline & & & Moderate & $12-14$ & 43 & 28.9 \\
\hline & & & Low & $9-11$ & 46 & 30.0 \\
\hline & & & Very low & $\leq 8$ & 8 & 4.0 \\
\hline & & & & & 149 & 100.0 \\
\hline \multirow[t]{6}{*}{3} & Mixed & Positive & Very high & $\geq 26$ & 16 & 10.7 \\
\hline & Reinforcement & & High & $21-25$ & 49 & 32.9 \\
\hline & & & Moderate & $16-20$ & 55 & 36.9 \\
\hline & & & Low & $11-15$ & 29 & 19.5 \\
\hline & & & Very low & $\leq 10$ & 0 & 0.0 \\
\hline & & & & & 149 & 100.0 \\
\hline \multirow[t]{2}{*}{4} & Negative & & Very high & $\geq 35$ & 0 & 0.0 \\
\hline & Reinforcement & & High & $29-34$ & 14 & 0.0 \\
\hline
\end{tabular}




\begin{tabular}{|c|c|c|c|c|c|}
\hline No & Sub Variabel & Categories & Interval & $\mathrm{f}$ & $\%$ \\
\hline & & Moderate & $23-28$ & 72 & 45.0 \\
\hline & & Low & $17-22$ & 61 & 55.0 \\
\hline & & Very low & $\leq 16$ & 2 & 0.0 \\
\hline & & \multicolumn{2}{|c|}{ Total } & 149 & 100.0 \\
\hline
\end{tabular}

Based on table 2, teacher reinforcement based on sub-variables of all aspects of reinforcement, namely aspects of positive verbal reinforcement is in the medium category with a percentage of $78.3 \%$; non-verbal positive reinforcement aspects are in the medium category with a percentage of $93.3 \%$; mixed positive reinforcement aspects are in the low category with a percentage of $57.1 \%$, and negative reinforcement is in the low category with a percentage of $55 \%$.

The teacher provides positive reinforcement both verbal and non-verbal which will affect the learning process followed by students, a positive impact on the student learning process such as students being responsible for the assignment given by the teacher, students paying attention to the teacher in delivering material, students will respond to questions from the teacher (Syarifuddin, 2016). The positive reinforcement research results were in the medium category with a percentage of $81.69 \%$. Verbal and nonverbal reinforcement aims to increase student learning motivation, teachers in providing reinforcement both verbally and non-verbally must be precise (Aini, Suandi, \&Nurjaya, 2018).

The provision of positive reinforcement has a good impact on students' learning attitudes to give birth to a generation that has quality human resources (Aini, Suandi, \&Nurjaya, 2018). Positive reinforcement given by teachers such as gifts and praise can encourage student motivation (Khasanah, KetutSuarni, \& Arum, 2014). Positive reinforcement is given by the teacher in the form of rewards, the teacher gives praise to students when students successfully complete the assignment. Meanwhile, negative reinforcement, where the teacher punishes students when they violate school regulations (Wibowo, 2015). Giving praise to students who comply with school regulations, help friends, give alms, and apologize easily (Zaturrahmi, Mudjiran, Neviyarni, \&Nirwana, 2020). Positive reinforcement is something that will strengthen the emergence of a response from a given stimulus, while negative reinforcement is something that will weaken the response to a given stimulus (Ahmad, 2010).

The results of research by Hannurofik (2016) state that teacher reinforcement is in the suboptimal category. The results of Misra's (2012) study also revealed that teachers' understanding of reinforcement, the ability of teachers to apply reinforcement, experiences of reinforcement received by students, and student acceptance of reinforcement from teachers were still in the sufficient category. the teacher has implemented reinforcement in the learning process but it is not fully optimized.

Teachers should encourage students to be active in the learning process, one way is to provide reinforcement (Prasetyanto, Wibawani, Wardani, \&Drajati, 2019). Teacher support in the form of positive reinforcement will affect classroom conditions (Khajavy, Ghonsooly, HosseiniFatemi, \& Choi, 2016). The reinforcement provided by the teacher will create a conducive atmosphere for the learning process (Mufidah\&Asmawi, 2017). Providing reinforcement appropriately supports academic success and the learning process that students follow (Aini et al., 2018).

Glading (2012) explains that there are several things that are important to do in the learning process between considering the relationship between teachers and students. 
Winnicott (Desra, 2014) states that a successful teacher is a teacher who empathizes with student problems, has the intuition to know when and where he must accompany students' struggles in achieving the goals they want, and provide more support. Teachers must have the ability to build good communication with students (Jaenuri, 2017). The education or learning process will not run well if the teacher is unable to build good relationships between teachers and students.

Be a teacher who always reinforces motivating students to learn (HarulAini, Suandi, \&Nurjaya, 2019). Teacher behavior is positively correlated with student academic achievement (Madukwe, Onwuka, \&Nyejirime, 2019). Teachers indirectly affect student learning outcomes at school (Marlina, Hendrawati, \&Kusumastuti, 2019); (Marlina\&Kusumastuti, 2019). The importance of reinforcement teachers in the learning process (Hoque, 2013). Using positive reinforcement has an impact on students' academic progress (Adibsereshki, Abkenar, Ashoori, \&Mirzamani, 2015). Positive reinforcement in the form of praise will encourage students to do the same behavior and will even try to improve for the better (Sholikhah, Yuwono, Sugiharto, \&Tadjri, 2017).

Guidance and counseling services are an integral part of education which has a role to help increase the effectiveness of reinforcing by subject teachers in the classroom. Efforts can be made by counseling teachers by providing guidance and counseling services (Emdorizal, Karneli, \&Marlina, 2019). The guidance and counseling services provided can provide an understanding of something (Kasman, Syukur, \&Marlina, 2018). BK teachers/school counselors provide consultation services to subject teachers related to the application of reinforcement skills to students (Al Halik et al., 2019). It is recommended that every teacher in the learning process reinforce each student appropriately because the reinforcement given by the teacher can improve student academic achievement (Nababan, 2018).

\section{Conclusion}

The low level of reinforcement of subject teachers given to students will affect learning outcomes and the learning process of students in schools. In general, it can be concluded that the level of reinforcement of subject teachers is in a low category. The lower the level of reinforcement of subject teachers, the less conducive a learning climate will be, thus affecting the learning process and student learning outcomes. Efforts are made to increase teacher reinforcement by providing training for subject teachers so that they have skills in providing reinforcement to students.

\section{References}

Abdillah. (2009). Kondisi kewibawaan, kewiyataan dan mutu kegiatan belajar siswa serta kaitannya dengan hasil belajar siswa. Program Pasca sarjana UNP.

Adibsereshki, N., Abkenar, S. J., Ashoori, M., \& Mirzamani, M. (2015). The effectiveness of using reinforcements in the classroom on the academic achievement of students with intellectual disabilities. Journal of Intellectual Disabilities, 19(1), 83-93. https://doi.org/10.1177/1744629514559313

Ahmad, R. (2010). Pengelolaan Pengajaran. Jakarta: Rineka Cipta.

Aini, Harul, Suandi, N., \& Nurjaya, G. (2019). Pemberian Penguatan (Reinforcement) Verbal Dan Nonverbal Guru Dalam Pembelajaran Bahasa Indonesia Di Kelas Viii Mtsn Seririt. Jurnal 
Pendidikan Bahasa Dan Sastra Indonesia Undiksha, 8(1). https://doi.org/10.23887/jjpbs.v8i1.20246

Aini, Hurul, Suandi, N., \& Nurjaya, G. (2018). Pemberian Penguatan ( Reinforcement ) Verbal dan Nonverbal Guru dalam Pembelajaran Bahasa Indonesia di Kelas VIII MTsN Seririt. Jurnal Pendidikan Bahasa Dan Sastra Indonesia Undiksha, 8(3), 23-32.

Aini, Z., Nirwana, H., \& Marjohan, M. (2018). Kontribusi Penguatan Guru Mata Pelajaran Dan Kepercayaan Diri Siswa Terhadap Keaktifan Siswa Dalam Belajar. Biblio Couns: Jurnal Kajian Konseling Dan Pendidikan, 1(1), 1-11. https://doi.org/10.30596/bibliocouns.v1i1.1941

Al Halik, Prayitno, \& Mudjiran. (2019). Aplikasi Penguatan kepada Siswa di Sekolah. INSIGHT: Jurnal Bimbingan Konseling, 8(1), 34-50. https://doi.org/10.21009/insight.081.04

Blazar, D., \& Kraft, M. A. (2017). Teacher and Teaching Effects on Students' Attitudes and Behaviors. Educational Evaluation and Policy Analysis, 39(1), 146-170. https://doi.org/10.3102/0162373716670260

Creswell, J. W. (2009). Research design qualitative, quantitative and mixed methods approaches. Amerika: Sage Publications.

Darmadi, H. (2010). Kemampuan dasar mengajar. Bandung: Alfabeta.

Desra, R. (2014). Hubungan kelekatan (attachment) terhadap guru dengan motivasi menghafal Al-Quran pada siswa SMPIT Al-Ihsan boarding school Pekanbaru. Universitas Islam Negeri Sultan Sarif Kasim Riau.

Elliot, Kratochwill, Littlefied, \& Travers. (1996). Educational Psychology. USA: Brown \& Benchmark.

Emdorizal, E., Karneli, Y., \& Marlina, M. (2019). The Use of Counseling Cognitive Behavior Therapy (CBT) Approach to Change Students' Attitudes toward Cheating Behavior at SMK 1 Gunung Talang. International Journal of Applied Counseling and Social Sciences, 1(1), 17-26.

Glading, S. T. (2012). konseling profesi yang menyeluruh (edisi keenam) (alih bahasa P. M winarno dan lilian yuwono. Jakarta: Indeks.

Hannurofik. (2016). Penguatan guru dalam proses pembelajaran (studi kasus pada SMA Negeri Kota Jambi). Universitas Negeri Padang.

Hasibuan, \& Moedjiono. (2009). Proses belajar mengajar. Bandung: Remaja Rosdakarya.

Hoque, S. R. (2013). "Effect of Reinforcement on Teaching - Learning Process." IOSR Journal of Humanities and Social Science, 7(1), 13-16. https://doi.org/10.9790/0837-0711316

Ismeirita. (2020). Pengaruh Lingkungan Keluarga, Penguatan Guru dan Motivasi Belajar Terhadap Hasil belajar Siswa Mata Pelajaran Dasar-Dasar Perbankan Kelas X Akuntansi di SMK Negeri Keahlian Bisnis Manajemen Kota Padang. Jurnal Sosial Dan Ilmu Ekonomi, 5(1), 89-103.

Jaenuri, J. (2017). Pengembangan Soft Skill Guru. Ta'allum: Jurnal Pendidikan Islam, 5(1), $123-140$. https://doi.org/10.21274/taalum.2017.5.1.123-140

Kasman, A., Syukur, Y., \& Marlina, M. (2018). Implementation of Group Guidance Services To Improve Student Understanding About Academic Procrastination. 3rd International Conference on Education, Islamic, 8-12. Padang.

Khajavy, G. H., Ghonsooly, B., Hosseini Fatemi, A., \& Choi, C. W. (2016). Willingness to Communicate in English: A Microsystem Model in the Iranian EFL Classroom Context. TESOL Quarterly, 50(1), 154-180. https://doi.org/10.1002/tesq.204

Khasanah, F. L., Ketut Suarni, N., \& Arum, D. (2014). Penerapan Konseling Behavioral Dengan Teknik Penguatan Positif Terhadap Peningkatan Motivasi Belajar Pada Siswa Berinteligensi Rendah Kelas Viii 4 Di Smp Negeri 2 Singaraja. Ejournal Undiksha Jurusan Bimbingan Konseling, 2(1), 204- 
269.

Koswara. (2008). Bagaimana menjadi guru kreatif. Bandung: Pribumi Mekar.

Kothari, C. R. (1990). research methodology methods and technique. JAIPUR (INDIA).

Madukwe, P., Onwuka, U., \& Nyejirime, W. Y. (2019). Teachers ' Atti tude as a Correlate of Students ' Academic Performance. International Journal of Research and Innovation in Social Science, 3(1), 205209.

Marlina, M., Hendrawati, T., \& Kusumastuti, G. (2019). Teachers' Attitude towards the Learning Achievement of Students with Learning Disabilities in Inclusive Schools. Journal of ICSAR, 3(1), 32-36. https://doi.org/10.17977/um005v3i12019p032

Marlina, M., \& Kusumastuti, G. (2019). Social participation of students with special eucational needs in inclusive elementary schools. Specialusis Ugdymas, 1(39), 121-132. https://doi.org/10.21277/se.v1i39.412

Misra, M. (2012). Reinforcement Skill dalam Pembelajaran PAI (Studi Kasus di SMA Bukit Barisan Padang). Al-Ta Lim Journal, 19(1), 38-45. https://doi.org/10.15548/jt.v19i1.7

Mufidah, I., \& Asmawi, H. (2017). Komunikasi Interpersonal dan Keterampilan Memberi Penguatan: Sebuah Analisa Korelasional terhadap Minat Belajar Siswa. Palapa: Jurnal Studi Keislaman Dan Ilmu Pendidikan, 5(2), 1-19. https://doi.org/10.36088/palapa.v5i2.43

Nababan, R. (2018). Hubungan Keterampilan Guru Memberi Penguatan (Reinforcement) dengan Hasil Belajar Siswa Kelas X SMA Perguruan Kristen Hosana Medan Tahun Pelajaran 2018/2019. Jurnal Civic Education, 1(1), 1-9.

Ningsih, S., Marjohan, M., \& Nirwana, H. (2018). Contribution of the Implementation of High-Touch Teachers and the Academic Self Concept of Student Learning Motivation In Mathematics Subject. International Journal of Research in Counseling and Education, 3(1), 59-66. https://doi.org/10.24036/0069za0002

Prasetyanto, B. T., Wibawani, D. A., Wardani, E. N., \& Drajati, N. A. (2019). Teacher's Reinforcements Affecting Students' Willingness to Communicate (WTC): A Photovoice in EFL Classroom. Indonesian Journal of EFL and Linguistics, 4(1), 57. https://doi.org/10.21462/ijefl.v4i1.98

Prasetyo, B \& Jannah, L. M. (2012). Metode penelitian kuantitatif:teori dan aplikasi. Jakarta: Raja Grafindo Persada.

Prayitno. (2009). Dasar Teori dan Praksis Pendidikan. Jakarta: PT Gramedia.

Prayitno. (2005). Studi pengembangan aplikasi high touch dan high tech dalam proses pembelajaran. Padang.

Rasto. (2015). Pembelajaran mikro (mengembangkan keterampilan mengajar guru profesional). Bandung: Alfabeta.

Sardiman. (2007). Interaksi dan motivasi belajar mengajar. Jakarta: Raja Wali Press.

Sholikhah, L. D., Yuwono, D., Sugiharto, P., \& Tadjri, I. (2017). Jurnal Bimbingan Konseling Model Konseling Kelompok dengan Teknik Penguatan Positif untuk Mereduksi Prokrastinasi Akademik Siswa Abstrak. Jurnal Bimbingan Konseling, 6(1), 62-67.

Soemanto, W. (2006). Psikologi Pendidikan. Jakarta: Rineka Cipta.

Syarifuddin, C. R. (2016). Pengaruh pemberian penguatan positif terhadap sikap belajar peserta didik pada mata pelajaran bahasa indonesia di mi darul istiqamah kecamatan pattalassang kabupaten gowa. 3(2), 60-70. https://doi.org/10.24252/auladuna.v3i2a2.2016

Wibowo, A. (2015). Aplikasi Reinforcement oleh Guru Mata Pelajaran dan Implikasinya terhadap 
Bimbingan dan Konseling. Guidena, 5(2), 16-30.

Zaturrahmi, Mudjiran, Neviyarni, \& Nirwana, H. (2020). Implementasi Layanan BK dalam Program Pendidikan Karakter di SDIT Adzkia 1 Padang. E-Tech, 8(1), 1-6. https://doi.org/10.1007/XXXXXX-XX-0000-00 